DOI: $10.2478 / \mathrm{v} 10014-011-0017-5$

COBISS Code 1.01

Agrovoc descriptors: triticum, varieties, cereal crops, stress, cold, adaptation, antioxidants, enzymes, leaves, chemical composition, starch, carbohydrates, damage, resistance to injurious , temperature resistance, factors, phenylalanine ammonia lyase, gas exchange

Agris category code: F60

\title{
Contrastive responses of spring and winter wheat cultivars to chilling and acclimation treatments
}

\author{
Roghieh HAJIBOLAND ${ }^{1 *}$, Ghader HABIBI ${ }^{2}$
}

Received: May 24, 2011; accepted: September 19, 2011.

Delo je prispelo 24. maja 2011, sprejeto 19. septembra 2011.

\begin{abstract}
Photosynthesis and antioxidant defense system were investigated under chilling stress without $\left(\mathrm{Ch}, 25-4^{\circ} \mathrm{C}\right)$ and with acclimation (AcCh, 14-4 ${ }^{\circ} \mathrm{C}$ ) in winter (Sabalan) and spring (Zagros) wheat (Triticum aestivum L.) cultivars. Maximum quantum efficiency of photosystem II and $\mathrm{CO}_{2}$ assimilation rate decreased in AcCh 'Zagros' but not in 'Sabalan', and in contrast, an increase in non-photochemical quenching was observed in 'Sabalan' but not in 'Zagros'. Reduction of leaf starch content was observed in both cultivars while total soluble carbohydrates increased only in 'Sabalan' under both $\mathrm{Ch}$ and $\mathrm{AcCh}$ treatments. Activity of superoxide dismutase was significantly higher in Ch plants and activity of ascorbate peroxidase and catalase was slightly higher in $\mathrm{Ch}$ and AcCh plants of both cultivars compared with control. Activity of peroxidase increased in $\mathrm{Ch}$ and AcCh plants of 'Zagros' while phenylalanine ammoialyase (PAL) activity increased in AcCh 'Sabalan'. Increase in the leaf content of $\mathrm{H}_{2} \mathrm{O}_{2}$ and malondialdehyde (MDA) was more prominent in 'Zagros' than in 'Sabalan'. According to our results, chilling tolerance in winter cultivar was associated with greater thermal dissipation, higher soluble carbohydrates content, greater PAL activity and lower $\mathrm{H}_{2} \mathrm{O}_{2}$ and MDA content. Furthermore, acclimated plants were not more protected against chilling injury compared with non-acclimated ones.
\end{abstract}

Key words: Antioxidant enzymes, leaf photochemistry, gas exchange, phenylalanine ammoialyase

\section{IZVLEČEK}

\section{RAZLIČEN ODZIV KULTIVARJEV JARE IN OZIMNE PŠENICE NA MRAZ IN AKLIMATIZACIJO}

Fotosinteza in antioksidantna obramba sta bili raziskovani $\mathrm{v}$ razmerah hladnega stresa brez aklimatizacije $\left(\mathrm{Ch}, 25-4{ }^{\circ} \mathrm{C}\right)$ in $\mathrm{z}$ aklimatizacijo (AcCh, $14-4{ }^{\circ} \mathrm{C}$ ) pri ozimni pšenici Triticum aestivum L. (cv. Sabalan) in jari pšenici (cv. Zagros). Maksimalna učinkovitost fotosistema II in asimilacije $\mathrm{CO}_{2}$ sta se zmanjšali pri AcCh za 'Zagros', toda ne pri kultivarju 'Sabalan'. Nasprotno od tega se je povečalo nefotokemično gašenje pri kultivarju 'Sabalan', a ne pri 'Zagros'. Pri obeh kultivarjih je bilo ugotovljeno manj škroba v listih, medtem ko se je vsebnost celokupnih topnih ogljikovodikov povečala pri 'Sabalan' pri obeh tretiranjih, Ch in AcCh. Aktivnost superoksidne dismutase je bila značilno večja pri rastlinah Ch, aktivnost askorbatne peroksidaze in katalaze je bila pri obeh kultivarjih malo višja pri razmerah $\mathrm{Ch}$ in AcCh v primerjavi s kontrolo. Aktivnost peroksidaze se je povečala pri rastlinah $\mathrm{Ch}$ in AcCh pri kultivarju 'Zagros' medtem ko se je aktivnost fenilalanin ammoialiase (PAL) povečala pri AcCh cv. 'Sabalan'. Povečanje koncentracije $\mathrm{H}_{2} \mathrm{O}_{2}$ in malondialdehida (MDA) je bilo bolj izrazito pri kultivarju 'Zagros' v primerjavi s kultivarjem 'Sabalan'. Glede na naše rezultate je toleranca na mraz pri ozimnem kultivarju povečana $\mathrm{z}$ večjim termalnim trošenjem in večjo vsebnostjo večjih topnih ogljikovodikov. Odpornost na mraz je pri ozimnih kultivarjih povezana $\mathrm{z}$ večjo aktivnostjo PAL ter nižjo vsebnostjo $\mathrm{H}_{2} \mathrm{O}_{2}$ in MDA. Nadalje, aklimatizirane rastline niso bile nič bolje zaščitene pred poškodbami zaradi mraza v primerjavi z neaklimatiziranimi.

Ključne besede: Antioksidantni encimi, fotokemija listov, izmenjava plinov, fenilalanin amoialiaza

\section{INTRODUCTION}

Low temperature is one of the most important stress factors limiting the growth and productivity of cereals
(Janda et al., 2003). Photosynthesis is highly sensitive to cold stress, which is the main reason for the reduction

\footnotetext{
1 Associate Professor of Plant Physiology, Plant Science Department, University of Tabriz, 51666-14779 Tabriz, Iran, * ehsan@tabrizu.ac.ir

2 Assistant Professor of Plant Physiology, Biology Department, University of Payame-Noor, 19395-46912 Tehran, Iran
} 
or cessation of growth and productivity of plants under low temperature (Liang et al., 2007). Reduction of photosynthetic capacity in plants exposed to low temperatures is related to photoinhibition as well as oxidative damage (Tambussi et al., 2004). Low temperatures decrease quantum efficiency of PS II, the activities of PS I, the ATP synthase and the stromal enzymes of the carbon reduction cycle (Allen and Ort 2001). Non-radiative energy dissipation that involve the xanthophyll cycle and indicated by non-photochemical quenching ( $\mathrm{qN}$ ) of fluorescence, represents an important mechanism for protecting the photosynthetic apparatus against potential damage induced by excess excitation energy (Kim et al., 2005).

Chilling temperatures increase the level of reactive oxygen species (ROS) mainly because of chillinginduced photoinhibition. Reduction in the rate of $\mathrm{CO}_{2}$ fixation due to low temperature stress leads to an inadequate supply of natural electron acceptor, NADP, resulting in an over-reduction of the reaction centers. Molecular oxygen may then act as an electron acceptor in place of $\mathrm{NADP}^{+}$, producing superoxide radical $\left(\mathrm{O}_{2}{ }^{-}\right)$ (Allen and Ort 2001). Antioxidant enzymes such as superoxide dismutase (SOD), ascorbate peroxidase (APX), catalase (CAT) and peroxidase (POD) can eliminate toxic oxygen by-products.

Increase in the activity of phenylalanine ammonia-lyase (PAL) is one of the main lines of cell acclimation against cold stress in plants (Leyva et al., 1995, Rivero et al., 2001). Following increased PAL activity, phenylpropanoid derivatives accumulate in chilling stressed plants and are thought to protect plants against cold injury (Rivero et al., 2001, Solecka and Kacperska 2003). Activity of polyphenol oxidase (PPO), catalysing the oxidation and hydroxylation of phenolics, increases in response to different types of stress which is related to the appearance of injuries caused in plants by thermal stress (Dixon and Paiva 1995).

Exposure of plants to a non-injurious low temperature induces a degree of chilling tolerance, allowing them to survive subsequent exposure of plants to more severe low temperatures (Anderson et al., 1995). This acclimation phenomenon involves distinct changes in protein and metabolite synthesis. It was reported that transcript and protein levels of various isozymes of POD were up-regulated in acclimated plants (Anderson et al., 1995).

Short-term, low-temperature stress results in an inhibition of sucrose biosynthesis which leads to a restriction in photophosphorylation. Cold acclimation of cereals results in an increase in photosynthetic capacity following increases in the activities of Rubisco and stromal and cytosolic fructose-1,6-bisphosphatase (Hurry et al., 1995). Winter wheat cultivars can be distinguished from spring cultivars by their ability to adjust their photosynthetic capacity upon cold acclimation which is associated with an increased resistance to photoinhibition (Savitch et al., 1997).

In this work, we examined the effect of chilling stress (4 $\left.{ }^{\circ} \mathrm{C}\right)$ without and with acclimation $\left(14^{\circ} \mathrm{C}\right)$ treatment on photochemical properties, gas exchange and the photosynthetic end products, sucrose and starch as well as antioxidant defense capacity in the winter wheat cultivar, 'Sabalan', and the spring wheat cultivar, 'Zagros'. We hypothesized that tested cultivars respond differently to chilling stress and cold acclimation regarding photosynthetic characteristics and antioxidative capacity.

\section{MATERIALS AND METHODS}

\section{Plant materials and treatments}

Seeds of two wheat (Ttriticun aestivum L.) cultivars were surface sterilized and germinated on moistened filter paper in dark. Five-day-old seedlings were transferred to Hoagland nutrient solution (Johnson et al., 1957) and pre-cultured for 5 days. Thereafter, 10-day-old plants with uniform size were selected and subjected to different temperature treatments. Control (Cont) plants were remained at $25^{\circ} \mathrm{C}$ and grown for two weeks. The second group $(\mathrm{Ch})$ was grown at $25{ }^{\circ} \mathrm{C}$ for one week then exposed to a chilling temperature of $4{ }^{\circ} \mathrm{C}$ for subsequent one week. The third group ( $\mathrm{AcCh}$ ) was exposed to an acclimation treatment of $14{ }^{\circ} \mathrm{C}$ for one week, followed by a one-week chilling treatment of $4{ }^{\circ} \mathrm{C}$. Defined temperatures refer to that during the light period, night temperatures were 2$3{ }^{\circ} \mathrm{C}$ lower. Plants were grown in a germinator at about 200 $\mu \mathrm{mol} \mathrm{m} \mathrm{m}^{-2} \mathrm{~s}^{-1}$ photosynthetic photon flux density, 18/6 h light/dark photoperiod and relative humidity of $60 / 70 \%$.

\section{Determination of chlorophyll fluorescence and gas exchange parameters}

Chlorophyll (Chl) fluorescence parameters were recorded using a portable fluorometer (OSF1, ADC Bioscientific Ltd., UK) on the third youngest, fully expanded and attached leaf. Dark-adapted leaves were used for determination of initial $\left(F_{0}\right)$, maximum $\left(F_{m}\right)$, variable $\left(F_{v}=F_{m}-F_{0}\right)$ fluorescence as well as maximum quantum yield of photosystem II (PS II) $\left(F_{v} / F_{m}\right)$. Light adapted leaves were used for measurement of steadystate $\left(\mathrm{F}_{\mathrm{s}}\right)$ and maximum $\left(F_{m}^{\prime}\right)$ fluorescence. Calculations were made for photochemical quenching $(q P)$, non- photochemical quenching $(q N)$ and effective quantum yield of PS II $\left(\Phi_{\text {PSII }}\right)$ according to Maxwell and Johnson (2000). Net assimilation 
rate $(A)$, transpiration rate $(E)$ and stomatal conductance $\left(g_{s}\right)$ were measured in parallel with $\mathrm{Chl}$ fluorescence measurements in the same leaf with a calibrated portable gas exchange system (LCA-4, ADC Bioscientific Ltd., UK) between 10:00 A.M. and 13:00 P.M under photosynthetic photon flux density of $200 \mu \mathrm{mol} \mathrm{m} \mathrm{s}^{-2}$ at the leaf surface.

\section{Determination of carbohydrates}

For determination of carbohydrates, leaves were homogenized in $100 \mathrm{mM}$ phosphate buffer $\left(\mathrm{pH} \mathrm{7.5)}\right.$ at $4^{\circ} \mathrm{C}$ and supernatant was used for determination of total soluble sugars whereas the pellets were kept for starch analysis according to the method described in Magné et al. (2006).

\section{Assay of enzymes activity}

Determination of the activity of antioxidant enzymes and concentration of related metabolites were undertaken according to optimized protocols described elsewhere (Hajiboland and Hasani, 2007). Total SOD activity was determined using monoformazan formation test. One unit of SOD was defined as the amount of enzyme required to induce a $50 \%$ inhibition of nitro blue tetrazolium (Merck) reduction as measured at $560 \mathrm{~nm}$, compared with control samples without enzyme aliquot. The activity of APX was assayed by recording the decrease in absorbance of ascorbic acid at 290 $\mathrm{nm}$ and was defined as the enzyme protein required for oxidation of ascorbic acid $\min ^{-1}$ at $25^{\circ} \mathrm{C}$. Activity of CAT was assayed by monitoring the decrease in absorbance of $\mathrm{H}_{2} \mathrm{O}_{2}$ at $240 \mathrm{~nm} \mathrm{~min}$. Peroxidase activity was assayed using the guaiacol test. The increase in absorbance at $470 \mathrm{~nm}$ was recorded at $25{ }^{\circ} \mathrm{C}$ over a period of $5 \mathrm{~min}$ and the activity was calculated as enzyme protein required for the formation of tetraguaiacol $\mathrm{min}^{-1}$. Lipid peroxidation was estimated from the amount of malondialdehyde (MDA) formed in a reaction mixture containing thiobarbituric acid (Sigma) at $532 \mathrm{~nm}$. The concentration of $\mathrm{H}_{2} \mathrm{O}_{2}$ was determined using potassium titanium-oxalate (Sigma) at $508 \mathrm{~nm}$. Soluble proteins were determined using a commercial Bradford reagent (Sigma) and bovine serum albumin (Merck) as standard (Hajiboland and Hasani 2007).

Activity of PAL was determined according to the method of Dickerson (et al., 1984) by measuring the absorbance of transcinnamic acid at $290 \mathrm{~nm}$ after a period of $30 \mathrm{~min}$ at $30^{\circ} \mathrm{C}$. For determination of PPO activity, the increase in the absorbance at $370 \mathrm{~nm}$, based on the disappearance of caffeic acid was followed for $5 \mathrm{~min}$ at $30{ }^{\circ} \mathrm{C}$ (Ruiz et al., 1999).

Experiments were under taken in complete randomized block design with 4 replications. Statistical analyses were carried out using sigma stat (3.02) with Tukey test $(\mathrm{P}<0.05)$.

\section{RESULTS AND DISCUSSION}

Dry matter production of both cultivars was not influenced significantly by temperature treatments likely because of relatively short term exposure of plants to chilling stress. Chilling and acclimation treatments did not affect maximum quantum yield of PS II $\left(F_{v} / F_{m}\right)$ in 'Sabalan', while caused a significant reduction of $F_{v} / F_{m}$ in 'Zagros' (Table 1). It is well documented that photosynthetic apparatus is sensitive to several environmental stresses and PS II appears to be preferentially affected by chilling stress (Zhang et al., 2010). Reduction of $F_{v} / F_{m}$ in 'Zagros' indicated either damage to PS II or reversible and photoprotective photoinhibition via down-regulation of PS II (Rosenqvist and van Kooten 2003). Although exposure to either low-temperature stress or cold acclimation did not affect $q P$ and $\Phi_{\text {PSII }}$ in both cultivars, it caused significant increase of $q N$ in 'Sabalan' but not 'Zagros'. Because reduction of $F_{v} / F_{m}$ in 'Zagros' was not associated with a significant rise of $q N$, it could be suggested that, depressed $F_{v} / F_{m}$ was mainly due to photodamage, rather than to a reversible photoinhibition. In contrast to 'Zagros', in 'Sabalan' an ability for effective thermal dissipation reflected in significant rise of $q N$, was likely one of the reasons for unaffected $F_{v} / F_{m}$ under low-temperature treatments. Thermal dissipation plays an important role in preventing over-reduction of PS II electron acceptors (Müller et al., 2001).

Net $\mathrm{CO}_{2}$ assimilation rate (A) was not significantly influenced by low temperatures in 'Sabalan'. In 'Zagros' in contrast, A was diminished that was surprisingly accompanied by significant increase in stomatal conductance $\left(g_{s}\right)$ (Table 1). Gas exchange measurements were replicated during following day in this experiment, but the same results were obtained. Nevertheless, regarding $g_{s}$ values, reduction of photosynthetic capacity in chilled 'Zagros' could be ascribed only to the non-stomatal limitation of photosynthesis including reduction of $F_{\sqrt{ }} / F_{m}$ following damage to photosynthetic apparatus (Allen and Ort, 2001) and impairment in utilization of electrons and absorbed light energy for $\mathrm{CO}_{2}$ fixation (Liang et al., 2007) that in turn accentuates photogeneration of ROS and photooxidative damage to PS II. 
Table 1. Dry weight (DW, mg plant ${ }^{-1}$ ) of shoot and root, chlorophyll fluorescence parameters including $F_{v} / F_{m}$ (maximum quantum yield of PS II), $q P$ (photochemical quenching), $q N$ (non-photochemical quenching) and $\Phi_{\text {PSII }}$ (effective quantum yield of PS II) and gas exchange parameters including net photosynthetic rate $\left(A, \mu \mathrm{mol} \mathrm{m} \mathrm{m}^{-2}\right)$, transpiration rate $\left(E, \mathrm{mmol} \mathrm{m}^{-2} \mathrm{~s}^{-1}\right)$ and stomatal conductance to water vapor $\left(g_{s}\right.$, $\mathrm{mol} \mathrm{m} \mathrm{m}^{-2}$ ) in the leaves of two cultivars of wheat (Triticum aestivum L. cvs. Sabalan and Zagros) under three temperature treatments including control $\left(25^{\circ} \mathrm{C}\right.$, Cont), chilling $\left(4^{\circ} \mathrm{C}, \mathrm{Ch}\right)$ and acclimation treatment followed by chilling stress $\left(14^{\circ} / 4^{\circ} \mathrm{C}, \mathrm{AcCh}\right)$. Data of each row within each cultivar followed by the same letter are not significantly different $(\mathrm{P}<0.05)$.

\begin{tabular}{|c|c|c|c|c|c|c|}
\hline \multicolumn{6}{|c|}{ Temperature Treatments } & \multirow{3}{*}{ Parameters } \\
\hline \multicolumn{6}{|c|}{ Zagros } & \\
\hline $\mathrm{AcCh}$ & $\mathrm{Ch}$ & Cont & $\mathrm{AcCh}$ & $\mathrm{Ch}$ & Cont & \\
\hline$\overline{67 \pm 9^{\mathrm{a}}}$ & $72 \pm 7^{\mathrm{a}}$ & $73 \pm 7^{\mathrm{a}}$ & $75 \pm 5^{\mathrm{a}}$ & $81 \pm 7^{\mathrm{a}}$ & $76 \pm 5^{\mathrm{a}}$ & Shoot DW \\
\hline $0.80 \pm 0.01^{b}$ & $0.82 \pm 0.01^{\mathrm{a}}$ & $0.83 \pm 0.01^{\mathrm{a}}$ & $0.81 \pm 0.02^{\mathrm{a}}$ & $0.81 \pm 0.01^{\mathrm{a}}$ & $0.82 \pm 0.01^{\mathrm{a}}$ & $F_{\mathrm{v}} / F_{m}$ \\
\hline $0.90 \pm 0.02^{\mathrm{a}}$ & $0.92 \pm 0.02^{\mathrm{a}}$ & $0.92 \pm 0.01^{\mathrm{a}}$ & $0.94 \pm 0.02^{\mathrm{a}}$ & $0.92 \pm 0.02^{\mathrm{a}}$ & $0.93 \pm 0.01^{\mathrm{a}}$ & $q P$ \\
\hline $0.18 \pm 0.07^{\mathrm{a}}$ & $0.12 \pm 0.09^{\mathrm{a}}$ & $0.08 \pm 0.04^{\mathrm{a}}$ & $0.27 \pm 0.09^{\mathrm{a}}$ & $0.17 \pm 0.09^{\mathrm{ab}}$ & $0.03 \pm 0.02^{b}$ & $q N$ \\
\hline $0.71 \pm 0.01^{\mathrm{a}}$ & $0.72 \pm 0.03^{\mathrm{a}}$ & $0.75 \pm 0.04^{\mathrm{a}}$ & $0.73 \pm 0.01^{\mathrm{a}}$ & $0.73 \pm 0.02^{\mathrm{a}}$ & $0.75 \pm 0.01^{\mathrm{a}}$ & $\Phi_{\text {PSII }}$ \\
\hline $1.5 \pm 0.4^{\mathrm{b}}$ & $2.4 \pm 0.7^{\mathrm{ab}}$ & $3.4 \pm 1.2^{\mathrm{a}}$ & $1.9 \pm 0.4^{\mathrm{a}}$ & $2.3 \pm 0.3^{\mathrm{a}}$ & $2.8 \pm 1.1^{\mathrm{a}}$ & $A$ \\
\hline $0.42 \pm 0.09^{a}$ & $0.56 \pm 0.17^{\mathrm{a}}$ & $0.65 \pm 0.07^{\mathrm{a}}$ & $0.45 \pm 0.20^{\mathrm{a}}$ & $0.33 \pm 0.06^{\mathrm{a}}$ & $0.43 \pm 0.09^{a}$ & E \\
\hline $1.63 \pm 0.31^{\mathrm{b}}$ & $2.37 \pm 0.49^{\mathrm{a}}$ & $0.82 \pm 0.09^{\mathrm{c}}$ & $0.73 \pm 0.21^{\mathrm{a}}$ & $1.09 \pm 0.71^{\mathrm{a}}$ & $0.72 \pm 0.03^{\mathrm{a}}$ & $g_{s}$ \\
\hline
\end{tabular}

Significant reduction of starch content of leaves (Table 2) indicated strong impairment in the photosynthetic carbon metabolism in both cultivars. Under lowtemperature stress conditions, a limited stimulation of the sucrose biosynthetic pathway and a restriction in starch synthesis might lead to reduced rates of $\mathrm{CO}_{2}$ assimilation as a consequence of decreased ATP production (Savitch et al., 1997). Similar extent of reduction in the starch content in winter and spring wheat cultivars indicated that both cultivars experienced a restriction in photosynthetic carbon metabolism. Nevertheless, and in contrast to 'Zagros', total soluble sugars rather increased in chilled 'Sabalan' leaves. It has been assumed that the accumulation of soluble carbohydrates during cold acclimation plays an important role in winter survival and probably results from the differential low-temperature sensitivity of the enzymes of starch and sucrose metabolism (Hurry et al., 1995).

Table 2. Content of starch and total soluble sugars $\left(\mathrm{mg} \mathrm{g}^{-1} \mathrm{FW}\right)$ in the leaves of two cultivars of wheat (Triticum aestivum L. cvs. Sabalan and Zagros) under three temperature treatments including control $\left(25^{\circ} \mathrm{C}\right.$, Cont $)$, chilling $\left(4^{\circ} \mathrm{C}, \mathrm{Ch}\right)$ and acclimation treatment followed by chilling stress $\left(14^{\circ} / 4^{\circ} \mathrm{C}, \mathrm{AcCh}\right)$. Data of each row within each cultivar followed by the same letter are not significantly different $(\mathrm{P}<0.05)$.

\begin{tabular}{lllllll}
\hline Temperature Treatments & & \\
\cline { 1 - 5 } Zagros & & \multicolumn{3}{c}{ Sabalan } & \\
\cline { 1 - 5 } AcCh & Ch & Cont & AcCh & Ch & Cont & \\
\hline $327 \pm 37^{\mathrm{b}}$ & $375 \pm 26^{\mathrm{ab}}$ & $439 \pm 40^{\mathrm{a}}$ & $395 \pm 39^{\mathrm{b}}$ & $367 \pm 33^{\mathrm{b}}$ & $530 \pm 28^{\mathrm{a}}$ & Starch \\
$15.2 \pm 1.1^{\mathrm{a}}$ & $14.7 \pm 1.8^{\mathrm{a}}$ & $13.7 \pm 1.7^{\mathrm{a}}$ & $17.3 \pm 0.4^{\mathrm{a}}$ & $17.3 \pm 0.9^{\mathrm{a}}$ & $12.2 \pm 0.4^{\mathrm{b}}$ & Soluble sugars \\
\hline
\end{tabular}

Activity of SOD increased significantly in Ch plants, while in the AcCh plants SOD activity did not differ with Cont ones (Figure 1). A slight increase of APX and CAT activity was observed in both cultivars and under chilling temperature with and without acclimation. In contrast, POD activity was increased in 'Zagros' but not in 'Sabalan' by both temperature treatments. Exposure of plants to chilling stress with or without acclimation caused significant accumulation of $\mathrm{H}_{2} \mathrm{O}_{2}$ and MDA not only in 'Zagros' but also in 'Sabalan' (Figure 1). However, increase of $\mathrm{H}_{2} \mathrm{O}_{2}$ and MDA content was only $20 \%$ and $29 \%$ in 'Sabalan', while the corresponding values for 'Zagros' was $51 \%$ and $117 \%$ respectively. A rapid, transient increase in the $\mathrm{H}_{2} \mathrm{O}_{2}$ level was detected in wheat plants after cold treatment (Janda et al., 2003). Accumulation of MDA as a common product of lipid peroxidation is a sensitive diagnostic index of oxidative injury caused by chilling stress (Tambussi et al., 2004). These results indicated that higher chilling tolerance in 'Sabalan' in comparison with 'Zagros' is due to less injured membranes. One possible mechanism contributing to lower MDA content in the 'Sabalan' is an efficient thermal dissipation of excess light energy leading to less ROS production and higher efficiency with which scavenging of ROS takes place. Comparison of activity of antioxidant enzymes in two tested cultivars demonstrated, however, that, 'Zagros' was not, at least enzymatically, less capable for scavenging ROS 
than 'Sabalan' and was rather more active because of significant rise of POD activity under low-temperature treatments. Greater accumulation of $\mathrm{H}_{2} \mathrm{O}_{2}$ is likely the result of greater production of $\mathrm{H}_{2} \mathrm{O}_{2}$ that exceeded scavenging capacity of plants. It is also likely that, other reactive oxygen species was not measured in this work such as $\mathrm{O}_{2}{ }^{-}$, were differentially produced in two cultivars and may be responsible for higher membrane damages in 'Zagros'.
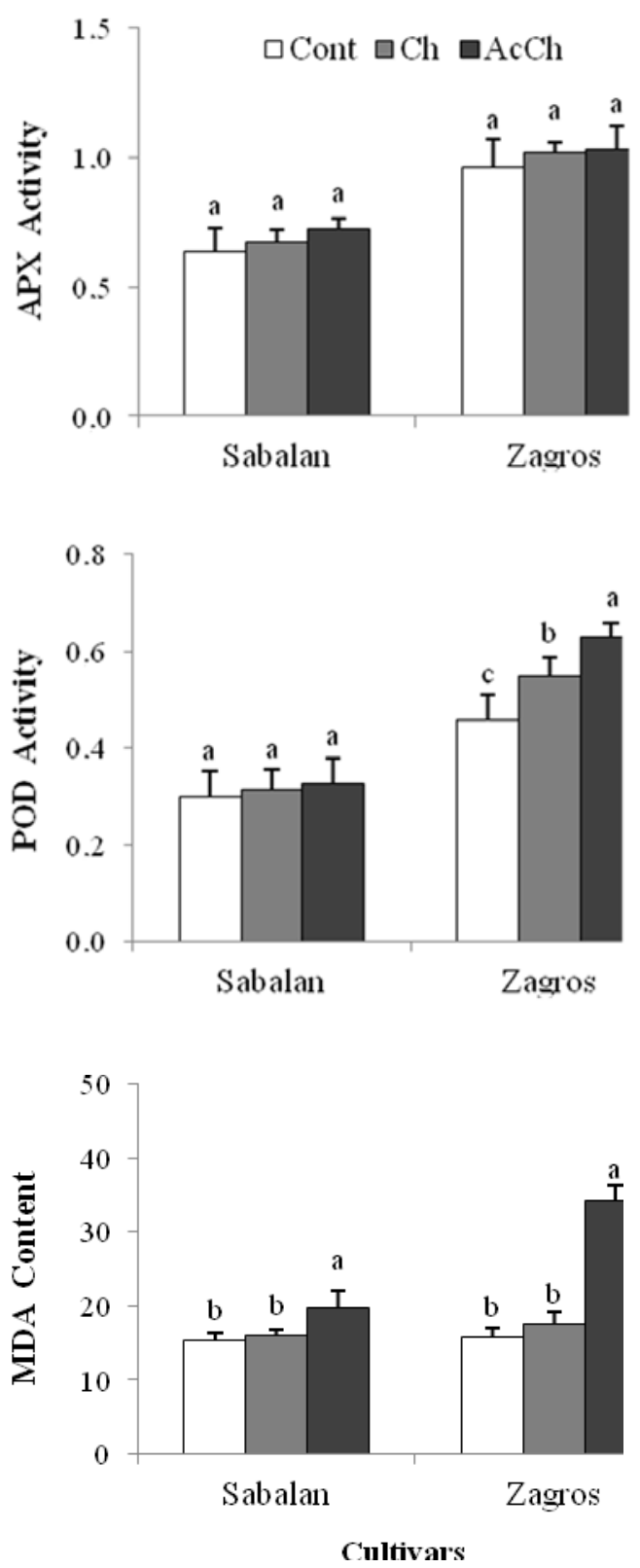

Figure 1. Specific activity of superoxide dismutase ( $\mathrm{SOD}, \mathrm{U} \mathrm{m} \mathrm{m}^{-1}$ Pro. $\mathrm{min}^{-1}$ ), ascorbate peroxidase (APX, $\mu \mathrm{mol}$ $\mathrm{mg}^{-1}$ Pro. $\mathrm{min}^{-1}$ ), catalase (CAT, $\mu \mathrm{mol} \mathrm{mg}{ }^{-1}$ Pro. $\mathrm{min}^{-1}$ ) and peroxidase (POD, $\mu \mathrm{mol} \mathrm{mg}{ }^{-1}$ Pro. $\mathrm{min}^{-1}$ ) and concentration of MDA (nmol g $\left.{ }^{-1} \mathrm{FW}\right)$ and $\mathrm{H}_{2} \mathrm{O}_{2}\left(\mu \mathrm{mol} \mathrm{g}{ }^{-1} \mathrm{FW}\right)$ in the leaves of two cultivars of wheat (Triticum aestivum L. cvs. Sabalan and Zagros) under three temperature treatments including control $\left(25^{\circ} \mathrm{C}\right.$, Cont), chilling $\left(4^{\circ} \mathrm{C}, \mathrm{Ch}\right)$ and acclimation treatment followed by chilling stress $\left(14^{\circ} / 4^{\circ} \mathrm{C}, \mathrm{AcCh}\right)$. Data of each row within each cultivar followed by the same letter are not significantly different $(\mathrm{P}<0.05)$.

Activity of PAL was influenced by AcCh treatments only in 'Sabalan' and PPO activity remained unchanged in both cultivars (Figure 2). In watermelon plants an acclimation against suboptimal temperatures consists of 
the accumulation of phenolics as a possible form of adapting to this stress (Rivero et al., 2001). Increase in the PAL activity and accumulation of different phenolics are thought to protect plants against various stressors (Solecka and Kacperska 2003). Higher PAL activity that caused likely phenolics accumulation may be one of the reasons for greater tolerance of 'Sabalan' to chilling temperatures.
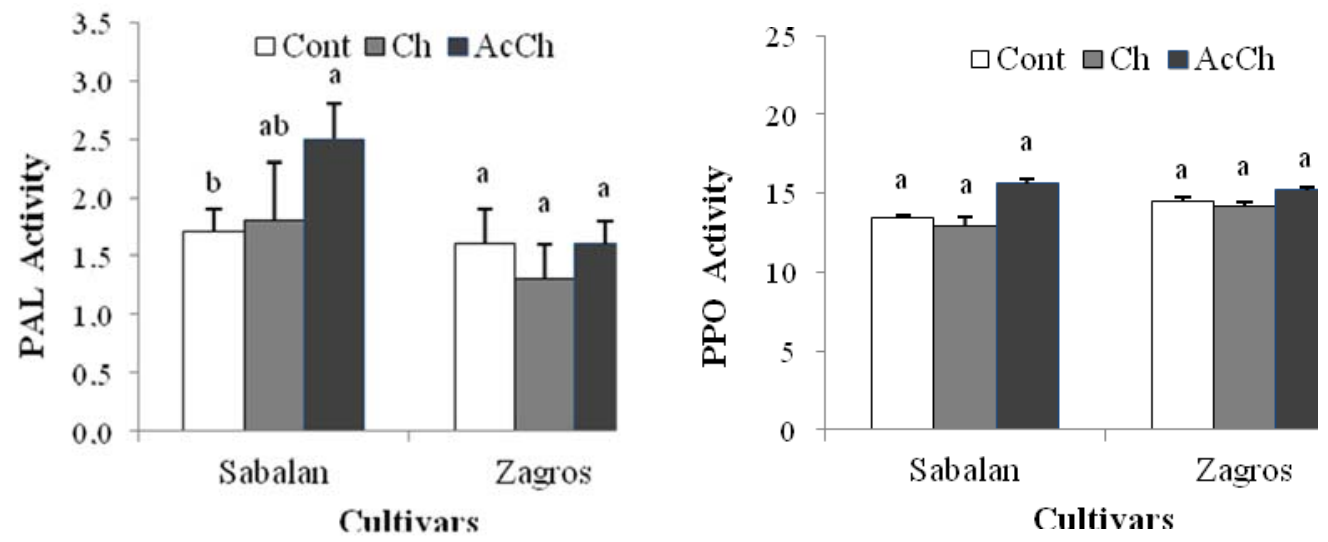

Figure 2. Specific activity of phenylalanine ammonia-lyase (PAL, $\mu$ mol cinnamic acid produced $\mathrm{mg}^{-1} \mathrm{Pro} \mathrm{min}^{-1}$ ) and polyphenol oxidase (PPO, $\mu \mathrm{mol}$ caffeic acid oxidized $\mathrm{mg}^{-1}$ Pro. $\mathrm{min}^{-1}$ ) in the leaves of two cultivars of wheat (Triticum aestivum L. cvs. Sabalan and Zagros) under three temperature treatments including control $\left(25^{\circ} \mathrm{C}\right.$, Cont), chilling $\left(4^{\circ} \mathrm{C}, \mathrm{Ch}\right)$ and acclimation treatment followed by chilling stress $\left(14^{\circ} / 4^{\circ} \mathrm{C}\right.$, $\mathrm{AcCh})$. Data of each row within each cultivar followed by the same letter are not significantly different $(\mathrm{P}<0.05)$.

Unexpectedly, the adverse effects of chilling stress on photochemical events, membrane integrity and $\mathrm{CO}_{2}$ assimilation, as well as its influence on $\mathrm{H}_{2} \mathrm{O}_{2}$ accumulation and activity of APX, CAT and POD in both cultivars were more prominent in AcCh compared with Ch plants. Lower injury of photosynthetic apparatus and membranes in Ch compared with AcCh plants is likely exposure for shorter time (1 week) of former plants to suboptimal temperatures than latter ones ( 2 weeks). It implicated also that growth at $14^{\circ} \mathrm{C}$ as acclimation treatment (Anderson et al., 1995) was not effective in protecting plants against chilling $\left(4^{\circ} \mathrm{C}\right)$ stress. It was also reported that, not only cold stress but also cold acclimation stimulates feed-back photosynthesis at the level of electron transport (Savitch et al., 1997). However, acclimation treatment would be likely effective if plants were exposed to freezing temperatures.

\section{REFERENCES}

Allen, D.J., Ort, D.R. 2001. Impacts of chilling temperatures on photosynthesis in warm-climate plants. Trends Plant Sci. 6: 36-42.

Anderson, M.D., Prasad, T.K., Stewart, C.R. 1995. Changes in isozyme profiles of catalase, peroxidase and glutathione reductase during acclimation to chilling in mesocotyls of maize seedlings. Plant Physiol. 109: 1247-1257.

Dickerson, D.P., Pascholati, S.F., Hagerman, A.E., Butler, L.G., Nicholson, R.L. 1984. Phenylalanine ammonialyase and hydroxycinnamate: CoA ligase in maize mesocotyls inoculated with Helminthosporium maydis or Helminthosporium carbonum. Physiol. Plant Pathol. 25: 111-123.
Dixon, R.A., Paiva, L. 1995. Stress-induced phenylpropanoid metabolism. Plant Cell 7: 1085-1097.

Hajiboland, R., Hasani, B.D. 2007. Responses of antioxidant defense capacity and photosynthesis of bean (Phaseolus vulgaris L.) plants to copper and manganese toxicity under different light intensities. Acta Biol. Szeged. 51: 93-106.

Hurry, V.M., Keerberg, O., Pärnik, T.P., Gardeström, P., Öquist, G. 1995. Cold hardening results in increased activity of enzymes involved in carbon metabolism in leaves of winter rye (Secale cereal L.). Planta 195: 554-562. 
Janda, T., Szalai, G., Rios-Gonzales, K., Veisa, O., Paldi, E. 2003. Comparative study of frost tolerance and antioxidant activity in cereals. Plant Sci. 164: 301-306.

Johnson, C.M., Stout, P.R., Broyer, T.C., Carlton, A.B. 1957. Comparative chloride requirements of different plant species. Plant Soil 8: 337-353.

Kim, J.-H., Kim, S.-J., Cho, S.H., Chow, W.S., Lee, C.-H. 2005. Photosystem I acceptor side limitation is a prerequisite for the reversible decrease in the maximum extent of P700 oxidation after short-term chilling in the light in four plants species with different chilling sensitivities. Physiol. Plant. 123: 100-107.

Leyva, A., Jarrillo, J.A., Salinas, J., Martinez-Zapater, M. 1995. Low temperature induces the accumulation of phenylalanine ammonia-lyase and chalcone synthase mRNA of Arabidopsis thaliana in light-dependent manner. Plant Physiol. 108: 39-46.

Liang, Y., Chen, H., Tang, M.-J., Yang, P.-F., Shen, S.-H. 2007. Responses of Jatropha curcas seedlings to cold stress: photosynthesis-related proteins and chlorophyll fluorescence characteristics. Physiol. Plant. 131: 508517.

Magné, C., Saladin, G., Clément, C. 2006. Transient effect of the herbicide flazasulfuron on carbohydrate physiology in Vitis vinifera L. Chemosphere 62: 650-657.

Maxwell, K., Johnson, G.N. 2000. Chlorophyll fluorescence a practical guide. J. Exp. Bot. 51: 659-668.

Müller, P., Li, X.P., Niyogi, K.K. 2001. Non-photochemical quenching. A response to excess light energy. Plant Physiol. 125: 1558-1566.
Rivero, R.M., Ruiz, J.M., García, P.C., Lípez-Lefebre, L.R., Sánchez, E., Romero, L. 2001. Resistance to cold and heat stress: accumulation of phenolic compounds in tomato and watermelon plants. Plant Sci. 160: 315321.

Rosenquist, E., van Kooten, O. 2003. chlorophyll fluorescence: a general description and nomenclature. In: Practical Applications of Chlorophyll Fluorescence in Plant Biology (Ed. by J.R. De Ell and P.M.A. Toivonen), Kluwer academic Publishers, Dordrecht, MA., USA: 32-77.

Ruiz, J.M., García, P.C., Rivero, R.M., Romero, L. 1999. Response of phenolic metabolism to the application of carbendazin plus boron in tobacco. Physiol. Plant. 106: $151-157$.

Savitch, L.V., Gray, G.R., Huner, N.P.A. 1997. Feedbacklimited photosynthesis and regulation of sucrose-starch accumulation during acclimation and low-temperature stress in a spring and winter wheat. Planta 201: 18-26.

Solecka, D., Kacperska, A. 2003. Phenylpropanoid deficiency affects the course of plant acclimation to cold. Physiol. Plant. 119: 253-262.

Tambussi, E.A., Bartoli, C.G., Guiamet, J.J., Beltrano, J., Araus, J.L. 2004. Oxidative stress and photodamage at low temperatures in soybean (Glycine max L. Merr.) leaves. Plant Sci. 167: 19-26.

Zhang, Y.H., Chen, L.J., He, J.L., Qian, L.S., Wu, L.Q., Wang, R.F. 2010. Characteristics of chlorophyll fluorescence and antioxidative system in super-hybrid rice and its parental cultivars under chilling stress. Biol. Plant. 54: 164-168. 